\title{
A Revisit of the Cross-Section of Overnight and Intraday Abnormal Returns: Evidence from the Japanese REIT Market
}

\author{
Jieting Chen ${ }^{1} \&$ Yuichiro Kawaguchi ${ }^{1,2}$ \\ ${ }^{1}$ Graduate School of Commerce, Waseda University, Tokyo, Japan \\ ${ }^{2}$ Graduate School of Business and Finance, Waseda University, Tokyo, Japan \\ Correspondence: Jieting Chen, Graduate School of Commerce, Waseda University, 1-6-1 Nishi-Waseda, \\ Shinjuku-ku, Tokyo, 169-8050, Japan. Tel: 81-909-948-0351. E-mail: jchen@asagi.waseda.jp
}

Received: October 28, 2017

Accepted: November 25, 2017

Online Published: December 5, 2017

doi:10.5539/ijef.v10n1p46

URL: https://doi.org/10.5539/ijef.v10n1p46

\begin{abstract}
This study revisits an overnight-intraday reversal strategy that generates an abnormal excess return for a stock market. The study is the first to examine whether abnormal returns related to size effect and investment effect occur overnight or intraday in the Japanese Real Estate Investment Trust (J-REIT) market. Empirical results show that in the J-REIT market, significant positive abnormal returns on investment effect as well as size effect occur intraday, followed by reversals that negative abnormal returns occur overnight. Further empirical results reveal that foreign institutional investors and individual investors trade against domestic institutional investors, and strengthen the asymmetric intraday and overnight abnormal returns. Therefore, we support the hypothesis that investor heterogeneity can explain the overnight-intraday anomaly. Moreover, the J-REIT market responds quickly and significantly to announcements from the Bank of Japan (BOJ). The information surprise caused by BOJ's announcements also intensifies the intraday and overnight abnormal returns in the J-REIT market.
\end{abstract}

Keywords: overnight-intraday anomaly, investment effect, size effect, Japanese REIT market

\section{Introduction}

In an efficient market, the stock price should reflect all information that is useful to investors. Therefore, no investor can obtain above-average profits by using public information and constructing any trading strategies. However, the concept of market efficiency has been subject to considerable debates in the finance literature. Many researchers find cross-sectional return patterns are linked to firm characteristics, such as market capitalization (Banz, 1981; Chan \& Chen, 1991), book-to-market values (Fama \& French, 1992, 1993), and real investment (Cooper \& Priestley, 2011; Fama \& French, 2015; Chen, 2017). It is shown that strategies based on a rich set of characteristics can earn excess abnormal returns.

As different subgroups of stocks may have distinguishable information that is available to investors, it is much more feasible to regard market efficiency as a matter of degree. A Real Estate Investment Trust (REIT) market is usually considered as an inefficient market because the return pattern of REITs is more or less similar to that of small-cap stocks. With the consideration that REIT stock price may not follow a random pattern but can be predictable, one can develop a trading strategy and earn excess abnormal returns. Many researchers provide evidence of the REIT-return predictability. Liu and Mei (1992) conclude that returns on REITs are more predictable than those on other common stocks. Furthermore, they find evidence that the January effect, the treasury-bill (T-bill) rate, and the capitalization rate on real estate can be used to predict REIT returns. Liao and Mei (1998) also find that returns on REIT stocks are more predictable than those on small stocks, and that market timing is useful in earning excess returns. Some researches provide possible trading strategies to earn excess abnormal returns. Mei and Liu (1994) find that buying REITs when excess returns for real estate market are expected to rise and selling REITs when excess returns for real estate market are expected to fall will generate higher excess return, compared with a buy-and-hold strategy. Based on the model of Wang (1994), Cooper, Downs, and Patterson $(1999,2000)$ construct a REIT investment strategy using filter rules, and show that this strategy yields significant abnormal returns. They find that abnormal returns are not only significant for weekly trading periods but also for longer investment periods up to one year.

However, although the short-term abnormal returns in REITs have been investigated on a weekly basis, no study 
has explored the REIT return predictability from a high-frequency basis. Meanwhile, the reversal of intraday and overnight abnormal returns is found to be significant in the common stock market. Branch and Ma (2012) use a large sample that spans from January 1, 1994 to December 31, 2010 and find a negative autocorrelation between adjacent overnight and intraday returns in the US market. The result is independent of the sampling method and robust to different methodologies. Similarly, Berkman, Koch, Tuttle, and Zhang (2012) also find a strong tendency for positive returns during the overnight period followed by reversals during the trading day. They further conclude that such behavior is driven by a relatively higher opening price on a particular trading day, and such phenomenon is more pronounced for stocks that attracted more attention from retail investors. Based on the different return patterns in daytime and overnight, Lou, Polk, and Skouras (2015) examine whether the momentum strategy and size strategy work in the daytime or the nighttime. They conclude that abnormal returns on the momentum strategy occur overnight, while those on the other strategies primarily occur intraday. The reason for momentum profits to occur overnight is that institutional investors trade against the momentum characteristic during the daytime. Inconsistent with the weak form of the efficient market hypothesis, the intraday and overnight return reversals create a potential market mispricing opportunity. However, a review of the previous literatures on REIT stock market indicates that the intraday and overnight abnormal return patterns have not been investigated yet. Therefore, this study is the first to investigate how cross-sectional anomalies vary in time-series.

Meanwhile, although numerous studies (see Tang \& Mori, 2017; Li \& Chau, 2016; Ong, Ooi, \& Kawaguchi, 2011) discussed the agency problem, long-term cycles and the acquisition problem in J-REIT market, none of them has focused on the temporal anomaly in the J-REIT market. Moreover, there is no consensus on the reasons that cause the intraday-overnight anomaly. Thus, we attempt to fill these gaps by utilizing the distinct features of the Japanese REIT market. On the one hand, J-REIT is highly influenced by the Bank of Japan (BOJ) (Ito, 2016), making it a natural setting to study the information surprise brought by macroeconomic news. Besides, J-REIT has experienced a manifest change in investor ownership since 2006, thus becoming a playfield to examine the relationship between investor heterogeneity and REIT abnormal returns. Therefore, we not only investigate the cross-sectional abnormal returns from an overnight-intraday basis, but also interpret that how investors ownership and macroeconomic news affect J-REIT price changes, thus leading new insights into the predictability of the Japanese REIT stock market.

The remainder of this paper is organized as follows. Section 2 introduces the sample data and key variables. Section 3 constructs strategies based on cross-sectional characteristics of investment level and market capitalization to capture the overnight and intraday abnormal returns. Section 4 conducts a subsample test and an event study to explore the role of investor heterogeneity and information surprise in interpreting the overnight and intraday abnormal return patterns. Section 5 summarizes and concludes the study.

\section{Data and Methodology}

\subsection{Data}

All REITs listed in the Tokyo Stock Exchange are investigated in this study. Semi-annual financial data, and daily open price and close price records of each J-REIT are collected from Sep.10, 2001 to May.20, 2016, provided by Japan REIT database. In total, there are 96861 firm-daily observations. Following the conventions for anomaly studies (Fama \& French, 2006), daily price data from April $1^{\text {st }}$ of year $t$ to March $31^{\text {st }}$ of year $t+1$ is matched with financial accounting data in the end of year t-1. Capital and Asset Pricing Model (CAPM), Fama and French Three-Factor Model and Five-Factor Model are adopted to calculate the risk-adjusted returns. The data of daily three factors and five factors specific for the Japanese stock market are obtained from K. French's online data library.

Besides, ownership ratios of each REIT are calculated based on the data from the J-REITs' Investor Relation (IR) materials. Also, we retrieve the dates and contents of market-related monetary policy announcements through the online Monetary Policy Meetings of Bank of Japan.

\subsection{Decomposed Returns}

To investigate the asymmetric return patterns in J-REIT, daily return of each REIT is decomposed into overnight return and intraday return using daily opening and closing prices. The total daily return of each REIT is the close-to-close price change, defined as the logarithmic change in successive daily closing prices. The overnight return is the close-to-open price change, which is the logarithmic difference in a particular day's opening price and previous day's closing price. Similarly, the intraday return is the open-to-close price change, calculated by the logarithmic difference in a particular day's opening price and closing price. 


$$
\begin{gathered}
R_{\text {Total }, t}^{i}=\ln \left(P_{\text {close }, t}^{i} / P_{\text {close }, t-1}^{i}\right) \\
R_{\text {Overnight }, t}^{i}=\ln \left(P_{\text {open }, t}^{i} / P_{\text {close }, t-1}^{i}\right) \\
R_{\text {Intraday }, t}^{i}=\ln \left(P_{\text {close }, t}^{i} / P_{\text {open }, t}^{i}\right)
\end{gathered}
$$

\subsection{Abnormal Returns}

This paper focuses on the abnormal returns that are related with characteristics. So two typical and classic characteristic-based return patterns, size effect (Chan, Chen, \& Hsieh, 1985; Fama \& French, 1992) and investment effect (Prombutra, Phengpisa, \& Zhang, 2012; Watanabe, Xu, Yao, \& Yu, 2013), are put the center of this study. Specifically, size effect reveals a return pattern that firms with smaller size (market capitalization) tend to have higher expected returns while big-size firms tend to have lower expected returns. Investment effect refers to a pattern that low-investment firms tend to have higher expected returns while high-investment firms tend to have lower expected returns. Following the conventions in previous study (Cooper, Gulen, \& Schill, 2008; Gray \& Johnson, 2011), firms' investment level is measured by the Asset Growth (AG).

$$
A G_{t-1}=\frac{T A_{t-1}-T A_{t-2}}{T A_{t-2}}
$$

where $\mathrm{TA}_{\mathrm{t}}$ refers to the total asset of each firm at time $\mathrm{t}$.

\subsection{Risk-Adjusted Returns}

In this paper, both raw returns as well as risk-adjusted returns are provided to measure the magnitude of abnormal return patterns during either night or daytime. A Capital Asset Pricing Model (CAPM), Fama-French Three-Factor Model and Fama-French Five-Factor Model (see eq. (5), eq. (6) and eq. (7)) are adopted to capture abnormal returns after controlling the common risk factors.

$$
\begin{gathered}
R_{i}-R_{f}=\alpha_{i}+\beta_{i} \cdot M K T_{i} \\
R_{i, t}-R_{f, t}=\alpha_{i}+\beta_{i} \cdot M K T_{i}+s_{i} \cdot S M B_{t}+h_{i} \cdot H M L_{t} \\
R_{i, t}-R_{f, t}=\alpha_{i}+\beta_{i} \cdot M K T_{i}+s_{i} \cdot S M B_{t}+h_{i} \cdot H M L_{t}+w_{i} \cdot R M W_{t}+c_{i} \cdot C M A_{t}
\end{gathered}
$$

The daily common risk factors shown in eq.(5) to eq.(7) are constructed based on the conventions of Fama and French $(1993,2016)$. MKT is the excess return of market portfolio. SMB (Small Minus Big) is the size factor. HML (High Minus Low) is the B/M factor. RMW (Robust Minus Weak) is the profitability factor. CMA (Conservative Minus Aggressive) is the investment factor. So the models above will adjust the portfolio raw returns by incorporating common risks premiums from Size, B/M, Profitability and Investment.

\subsection{Methodology}

The method of univariate sorts is applied in this analytical research. Consistent with many of the prior studies that examine the association between stock characteristics and returns, such as Jegadeesh and Titman (1993) and Pastor and Stambaugh (2003), portfolios are formed based on firm characteristics and held for one year. Return patterns across all the portfolios will reveal whether abnormal returns exist in the J-REIT market. The process is shown in Figure 1.

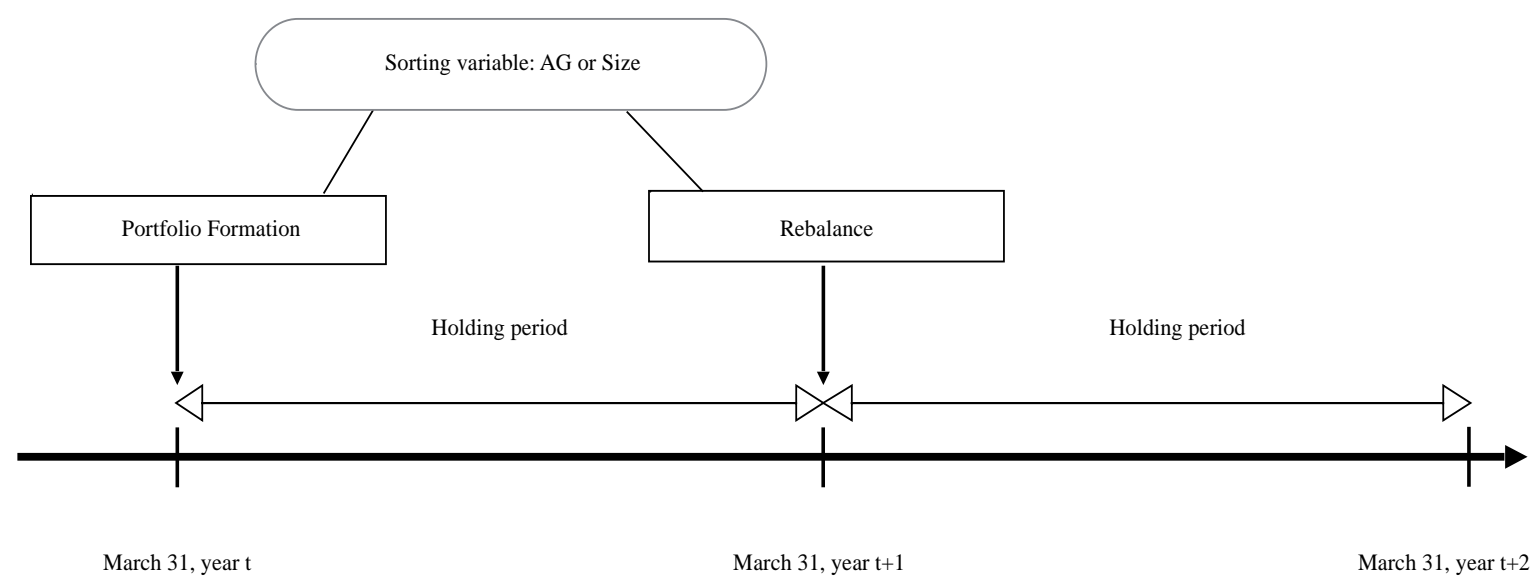

Figure 1. Sorting methodology

Note. This figure describes the methodology of univariate sorting. Every year in the end of March, all J-REITs are sorted and allocated into three portfolios based on the last year sorting variable: either AG or Size. The portfolios are held for one year and rebalanced the next year. 


\section{Overnight and Intraday Abnormal Returns}

\subsection{Strategies that Condition on Investment Level}

We first investigate the decomposed daily returns for investment-related portfolios. In the end of March every year, all REITs are ranked and allocated into three portfolio based on their last year Asset Growth rate (AG). The three portfolios, Low, Medium and High are rebalanced every year. A spread portfolio of "Low minus High" $(\mathrm{LMH})$ is also formed to capture the abnormal return dispersion that is related with characteristic of investment level (AG). Their average excess returns and risk-adjusted returns are estimated and reported in Table 1. T-statistics are estimated using Newey-West (1987) standard errors with 3 lags and listed in the parenthesis.

Panel A of Table 1 reports the total daily returns for each group. The average returns for each group are not significant. Also, there is no significant difference between low-investment group and high-investment group. Therefore, under the total daily return level, there is no investment effect in the Japanese REIT market.

However, if considering the overnight return, as shown in Panel B of Table 1, we find either raw excess returns or risk-adjusted returns of low-investment group are significantly smaller than those of high-investment group, revealing that the spread portfolio of "Low minus High" retains significant negative average returns. Specifically, the raw excess return dispersion between low and high investment portfolios is $-0.03 \%$ with t-statistics of -2.06 . The CAPM adjusted return dispersion is $-3.45 \%$ (t-statistic of -2.43 ), while the Fama-French Three-Factor adjusted and Five-Factor adjusted return dispersions are $-3.53 \%$ and $-3.58 \%$, respectively. Contrary to the definition of investment effect, which states that low-investment firms have higher expected returns while high-investment firms have lower expected returns, our investigation on overnight return reveals that a significant reversed investment effect exists in the J-REIT market.

When observing the intraday return, results in Panel C of Table 1 show a completely reversed return pattern for the J-REIT market. It is found that either raw excess returns or risk-adjusted returns of low-investment group are larger than those of high-investment group. So a significant positive average return for the spread portfolio of "Low minus High" can be observed. The positive investment-related abnormal returns are all significant at 99\% confidence level, indicating a significant investment effect in the daytime J-REIT market.

Table 1. Overnight and intraday returns for investment-sorted portfolios

\begin{tabular}{|c|c|c|c|c|c|}
\hline \multicolumn{6}{|c|}{ Panel A: Daily Abnormal Return } \\
\hline \multicolumn{2}{|c|}{ AG Rank } & Excess Return & CAPM Alpha & FF3 Alpha & FF5 Alpha \\
\hline \multirow[t]{4}{*}{ Low } & 1 & 0.0003 & 0.0118 & 0.0084 & 0.0099 \\
\hline & & $(1.20)$ & $(0.52)$ & $(0.37)$ & $(0.44)$ \\
\hline & 2 & 0.0002 & 0.0025 & 0.0022 & 0.0036 \\
\hline & & $(0.84)$ & $(0.11)$ & $(0.09)$ & $(0.15)$ \\
\hline \multirow[t]{2}{*}{ High } & 3 & 0.0001 & -0.0099 & -0.0119 & -0.0098 \\
\hline & & $(0.26)$ & $(-0.36)$ & $(-0.44)$ & $(-0.37)$ \\
\hline \multirow{2}{*}{\multicolumn{2}{|c|}{ Low-High }} & 0.0002 & 0.0171 & 0.0157 & 0.0150 \\
\hline & & $(1.31)$ & $(1.01)$ & $(0.95)$ & $(0.91)$ \\
\hline \multicolumn{6}{|c|}{ Panel B: Overnight Abnormal Return } \\
\hline \multicolumn{2}{|c|}{ AG Rank } & Excess Return & CAPM Alpha & FF3 Alpha & FF5 Alpha \\
\hline \multirow[t]{4}{*}{ Low } & 1 & -0.0009 & -0.0999 & -0.1009 & -0.1008 \\
\hline & & $(-5.00)$ & $(-6.16)$ & $(-6.13)$ & $(-6.08)$ \\
\hline & 2 & -0.0006 & -0.0755 & -0.0753 & -0.0750 \\
\hline & & $(-3.53)$ & $(-4.71)$ & $(-4.59)$ & $(-4.55)$ \\
\hline \multirow[t]{2}{*}{ High } & 3 & -0.0006 & -0.0699 & -0.0702 & -0.0695 \\
\hline & & $(-2.64)$ & $(-3.45)$ & $(-3.46)$ & $(-3.42)$ \\
\hline \multirow{2}{*}{\multicolumn{2}{|c|}{ Low-High }} & $-0.0003 * *$ & $-0.0345^{* *}$ & $-0.0353 * *$ & $-0.0358^{* *}$ \\
\hline & & $(-2.06)$ & $(-2.43)$ & $(-2.51)$ & $(-2.56)$ \\
\hline \multicolumn{6}{|c|}{ Panel C: Intraday Abnormal Return } \\
\hline \multicolumn{2}{|c|}{ AG Rank } & Excess Return & CAPM Alpha & FF3 Alpha & FF5 Alpha \\
\hline \multirow[t]{4}{*}{ Low } & 1 & 0.0012 & 0.1071 & 0.1047 & 0.1061 \\
\hline & & $(5.83)$ & $(5.47)$ & $(5.39)$ & $(5.47)$ \\
\hline & 2 & 0.0008 & 0.0734 & 0.0728 & 0.0741 \\
\hline & & $(3.96)$ & $(3.60)$ & $(3.59)$ & (3.64) \\
\hline \multirow[t]{2}{*}{ High } & 3 & 0.0006 & 0.0555 & 0.0537 & 0.0552 \\
\hline & & (3.22) & $(2.86)$ & $(2.81)$ & $(2.91)$ \\
\hline
\end{tabular}




\begin{tabular}{|c|c|c|c|c|}
\hline Low-High & $\begin{array}{c}0.0005 * * * \\
(3.76)\end{array}$ & $\begin{array}{c}0.0471 \text { *** } \\
(3.37)\end{array}$ & $\begin{array}{c}0.0464 * * * \\
(3.35)\end{array}$ & $\begin{array}{c}0.0463^{* * *} \\
(3.34)\end{array}$ \\
\hline
\end{tabular}

Note. ${ }^{* *} \mathrm{p}<0.05,{ }^{* * *} \mathrm{p}<0.01$. "Excess Return" is the average raw returns. "CAPM Alpha" is the risk-adjusted portfolio return estimated by CAPM. "FF3 Alpha" is the risk-adjusted portfolio return estimated by Fama and French Three-Factor Model. "FF5 Alpha" is the risk-adjusted portfolio return estimated by Fama and French Five-Factor Model. T-statistics are estimated using Newey-West (1987) standard errors with 3 lags and reported in parenthesis.

Figure 2 to Figure 4 plots the average total and decomposed daily returns for three investment-related portfolios and the spread portfolio (LMH) throughout the sample period. As shown in Figure 2, there is no sustained return pattern for each group. However, in Figure 3, the overnight returns are mostly negative and the low-AG group has the smallest average returns. The triangle shadow area shows the average returns for the spread portfolio (LMH), indicating that overnight investment-related abnormal returns are mostly negative. Contrarily, as shown in Figure 4, the average intraday returns are positive and the low-AG group has the largest average returns. The triangle shadow area reveals that average returns for the spread portfolio are mostly positive in daytime.

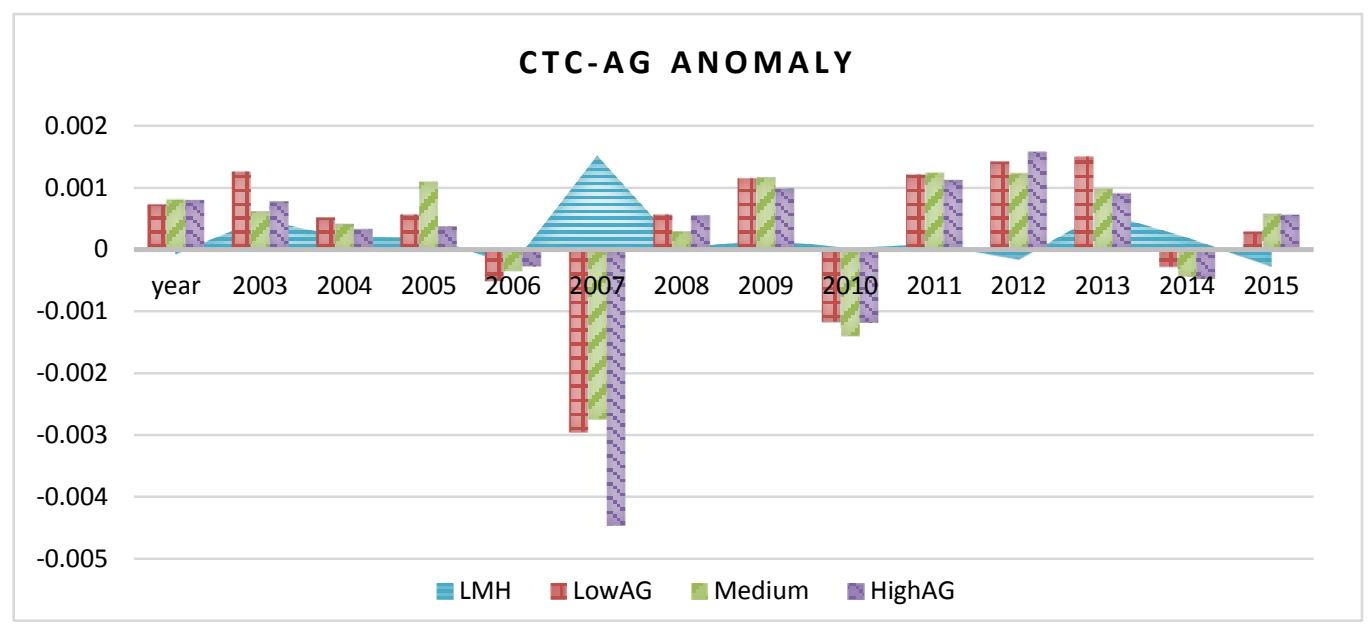

Figure 2. Average investment-related total daily returns throughout sample period

Note. This figure reports the yearly average raw returns for each investment-related portfolios and the spread portfolio of "Low minus High" (LMH) based on the total daily return (CTC).

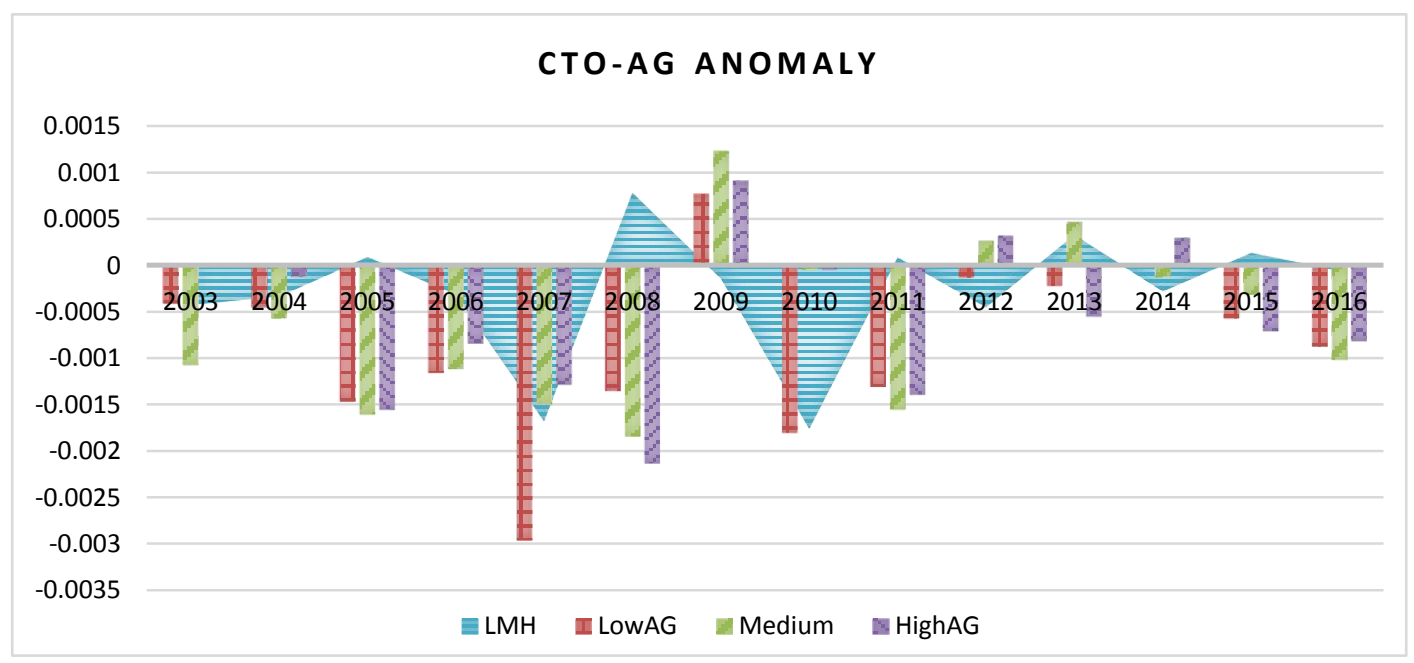

Figure 3. Average investment-related overnight returns throughout sample period

Note. This figure reports the yearly average raw returns for each investment-related portfolios and the spread portfolio of "Low minus High" (LMH) based on the decomposed overnight return (CTO). 


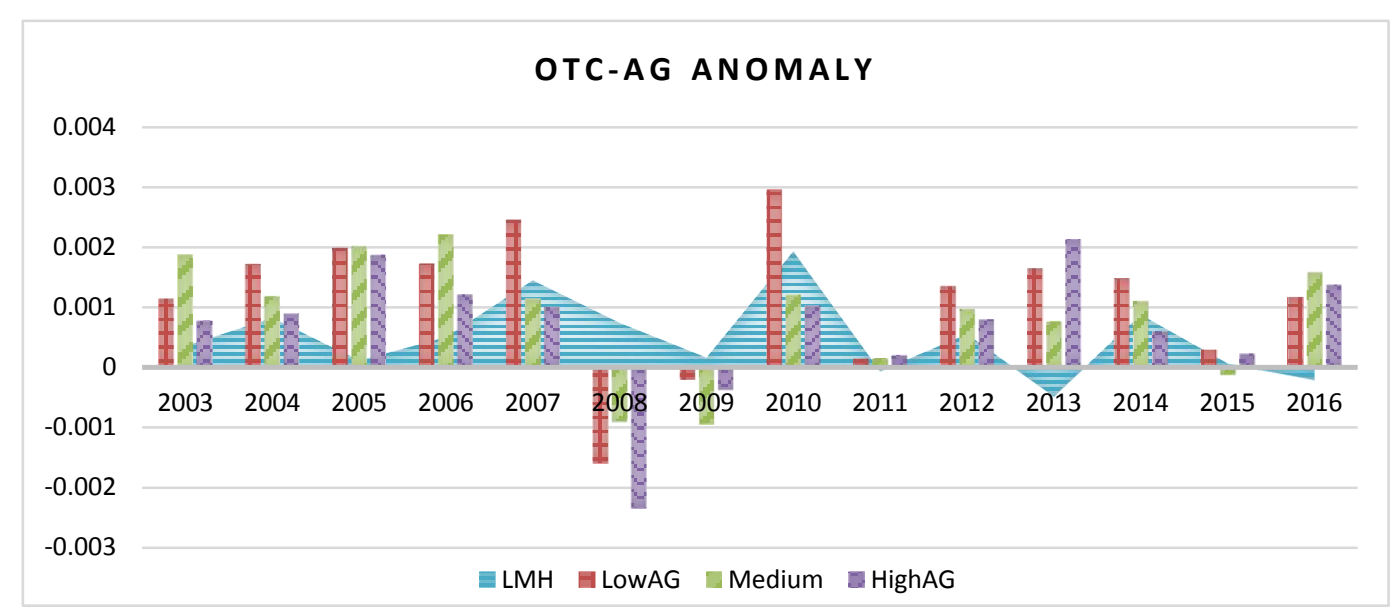

Figure 4. Average investment-related intraday returns throughout sample period

Note. This figure reports the yearly average raw returns for each investment-related portfolios and the spread portfolio of "Low minus High" (LMH) based on the decomposed intraday return (OTC).

To sum up, positive abnormal returns related to investment effect occur during daytime, followed by reversals that negative abnormal returns related to investment effect occur overnight. A strategy that buying low-investment REITs and selling high-investment REITs around opening period, while selling low-investment REITs and buying high-investment REITs around closing period, will capture the intraday investment effect and the overnight reversed investment effect simultaneously and generate an excess return of as much as $0.08 \%$ per day.

\subsection{Strategies that Condition on Size}

After observing the asymmetric intraday and overnight investment-related abnormal returns, we further study the abnormal returns related to size to clarify whether this is a specific or a general phenomenon. The same approach is adopted in this section. In the end of March every year, all REITs are allocated equally into three groups by their last year-end market capitalization, size. Three portfolios, Small, Medium and Big are formed and rebalanced every year. Also a spread portfolio of "Small minus Big" (SMB) is formed to capture the abnormal return that is related with characteristic of firm size. Table 2 reports the average total daily return and the decomposed daily return for each portfolio.

Panel A of Table 2 reports the total daily return. We find no significant return patterns for different size-based portfolios. However, as Panel B reveals, small-size group has generally smaller average excess return and risk-adjusted returns than the big-size group. So the spread portfolio of SMB has as large as $-0.05 \%$ of abnormal excess return, $-5.29 \%$ of abnormal CAPM alpha, $-5.53 \%$ of abnormal Fama-French three-factor alpha, and -5.65\% of Fama-French five-factor alpha. All of the figures are significant at $99 \%$ confidence level.

Panel C of Table 2 reports the average intraday returns for each group. Contrary to the results in Panel B, results in Panel $\mathrm{C}$ shows that small-size group has generally larger average excess return and risk-adjusted returns than big-size group. The spread portfolio of SMB retains a significant positive return. The return pattern in Panel C implies a typical size effect while the return pattern in Panel B reveals a reversed size effect. Thus, we find significant asymmetric return patterns for size-related abnormal returns in daytime and nighttime.

Table 2. Overnight and intraday returns for size-sorted portfolios

\begin{tabular}{|c|c|c|c|c|}
\hline \multicolumn{5}{|c|}{ Panel A: Daily Abnormal Return } \\
\hline Size Ran & Excess Return & CAPM Alpha & FF3 Alpha & FF5 Alpha \\
\hline \multirow[t]{4}{*}{ Small } & 0.0002 & 0.0028 & -0.0015 & 0.0000 \\
\hline & $(0.66)$ & $(0.11)$ & $(-0.06)$ & $(0.00)$ \\
\hline & 0.0002 & 0.0082 & 0.0052 & 0.0066 \\
\hline & $(0.95)$ & $(0.36)$ & $(0.23)$ & $(0.29)$ \\
\hline \multirow[t]{2}{*}{ Big } & 0.0002 & 0.0034 & 0.0038 & 0.0067 \\
\hline & $(0.81)$ & $(0.15)$ & $(0.17)$ & $(0.31)$ \\
\hline \multirow[t]{2}{*}{ Small-Biş } & -0.0000 & -0.0054 & -0.0101 & -0.0115 \\
\hline & $(-0.15)$ & $(-0.29)$ & $(-0.55)$ & $(-0.63)$ \\
\hline
\end{tabular}




\begin{tabular}{|c|c|c|c|c|c|}
\hline \multicolumn{6}{|c|}{ Panel B: Overnight Abnormal Return } \\
\hline \multicolumn{2}{|c|}{ Size Rank } & Excess Return & CAPM Alpha & FF3 Alpha & FF5 Alpha \\
\hline \multirow[t]{4}{*}{ Small } & 1 & -0.0008 & -0.0925 & -0.0946 & -0.0950 \\
\hline & & $(-4.83)$ & $(-5.72)$ & $(-5.77)$ & $(-5.73)$ \\
\hline & 2 & -0.0007 & -0.0816 & -0.0819 & -0.0815 \\
\hline & & $(-4.02)$ & $(-4.98)$ & $(-4.91)$ & $(-4.83)$ \\
\hline \multirow[t]{2}{*}{ Big } & 3 & -0.0003 & -0.0443 & -0.0441 & -0.0433 \\
\hline & & $(-1.90)$ & $(-2.86)$ & $(-2.78)$ & $(-2.70)$ \\
\hline \multirow{2}{*}{\multicolumn{2}{|c|}{ Small-Big }} & $-0.0005^{* * *}$ & $-0.0529 * * *$ & $-0.0553 * * *$ & $-0.0565 * * *$ \\
\hline & & $(-3.81)$ & $(-3.98)$ & $(-4.15)$ & $(-4.23)$ \\
\hline \multicolumn{6}{|c|}{ Panel C: Intraday Abnormal Return } \\
\hline \multicolumn{2}{|c|}{ Size Rank } & Excess Return & CAPM Alpha & FF3 Alpha & FF5 Alpha \\
\hline \multirow[t]{4}{*}{ Small } & 1 & 0.0010 & 0.0904 & 0.0883 & 0.0902 \\
\hline & & $(5.38)$ & $(5.06)$ & $(5.02)$ & $(5.16)$ \\
\hline & 2 & 0.0009 & 0.0850 & 0.0823 & 0.0833 \\
\hline & & (4.69) & $(4.36)$ & $(4.26)$ & $(4.31)$ \\
\hline \multirow[t]{2}{*}{ Big } & 3 & 0.0005 & 0.0429 & 0.0431 & 0.0452 \\
\hline & & (2.57) & (2.21) & $(2.22)$ & $(2.32)$ \\
\hline \multirow{2}{*}{\multicolumn{2}{|c|}{ Small-Big }} & $0.0005^{* * *}$ & $0.0427 * * *$ & $0.0404 * *$ & $0.0402 * *$ \\
\hline & & $(2.95)$ & $(2.65)$ & $(2.51)$ & $(2.48)$ \\
\hline
\end{tabular}

Note. $* * p<0.05, * * * p<0.01$. "Excess Return" is the average raw returns. "CAPM Alpha" is the risk-adjusted portfolio return estimated by CAPM. "FF3 Alpha" is the risk-adjusted portfolio return estimated by Fama and French Three-Factor Model. "FF5 Alpha" is the risk-adjusted portfolio return estimated by Fama and French Five-Factor Model. T-statistics are estimated using Newey-West (1987) standard errors with 3 lags and reported in parenthesis.

Figure 5 to Figure 7 sketches the yearly average returns for each size-related portfolios based on the close-to-close total daily return, the close-to-open overnight return, and the open-to-close intraday return. Same as the results in Table 2, Figure 5 to Figure 7 reveal that size effect occurs during daytime but the reversed size effect offsets the abnormal returns and leads to an insignificant total daily return pattern. The abnormal excess return earned by the strategy of buying small REITs and selling big REITs around the opening period while selling small REITs and buying big REITs around the closing period will be as much as $0.1 \%$.

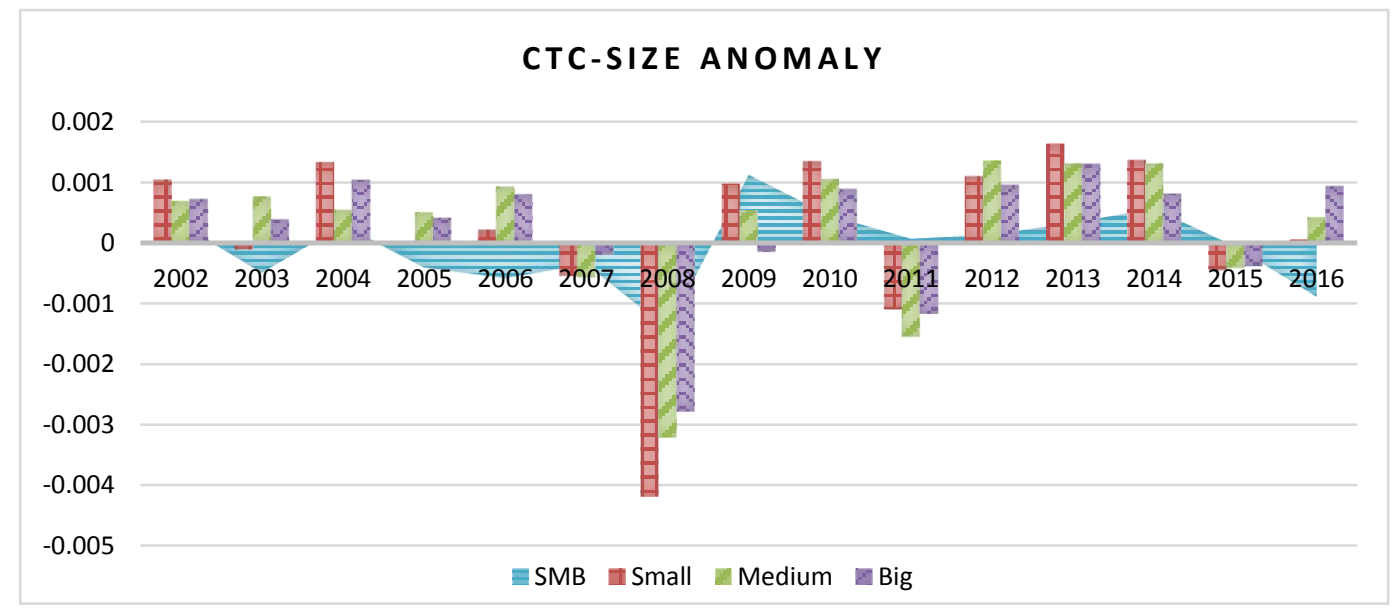

Figure 5. Average Size-related Total Daily Returns throughout Sample Period

Note. This figure reports the yearly average raw returns for each size-related portfolios and the spread portfolio of "Small minus Big" (SMB) based on the total daily return (CTC). 


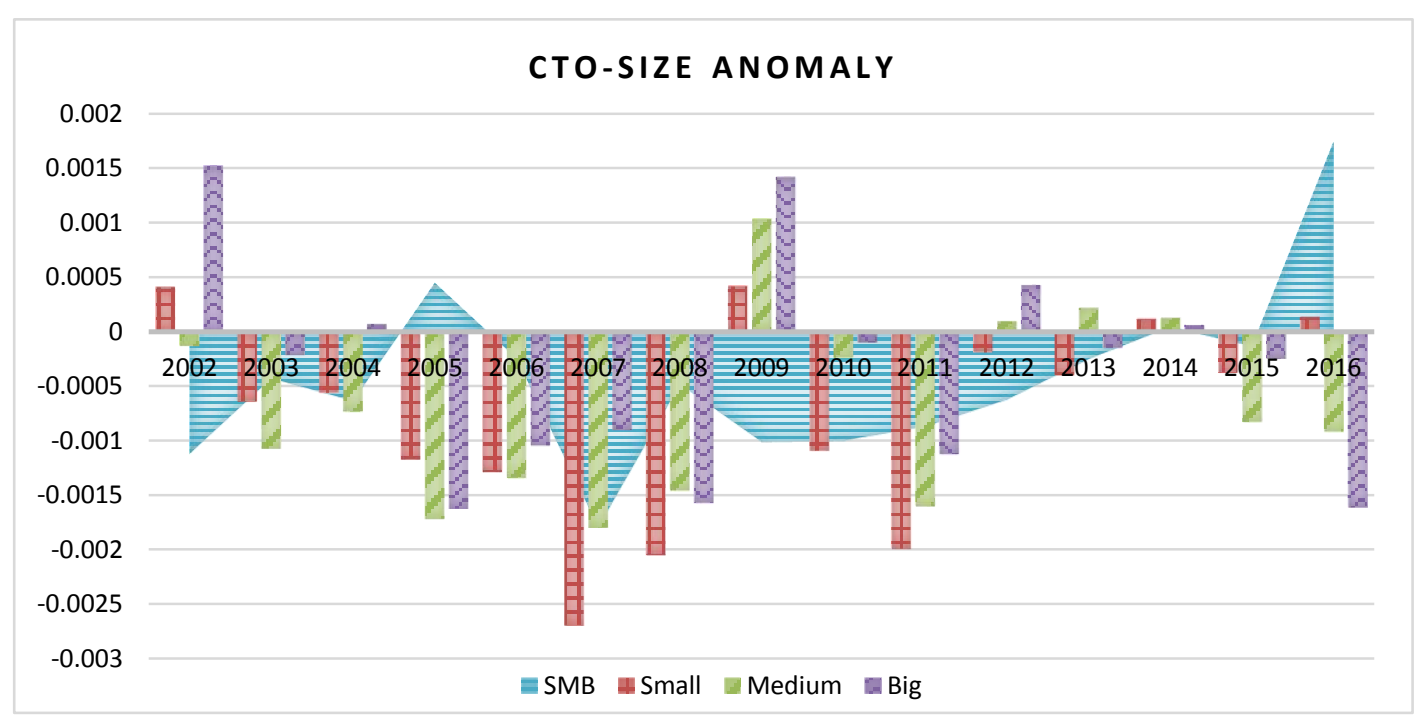

Figure 6. Average size-related overnight returns throughout sample period

Note. This figure reports the yearly average raw returns for each size-related portfolios and the spread portfolio of "Small minus Big" (SMB) based on the decomposed overnight return (CTO).

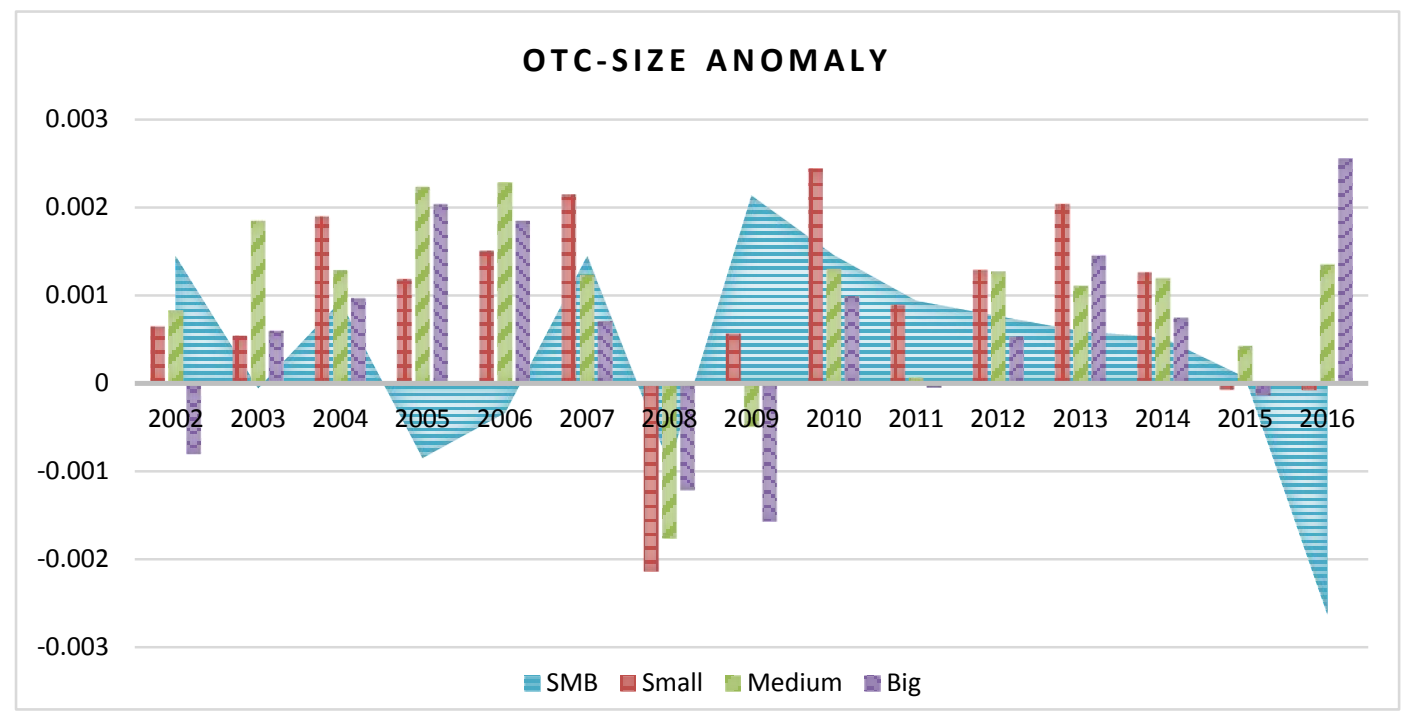

Figure 7. Average size-related intraday returns throughout sample period

Note. This figure reports the yearly average raw returns for each size-related portfolios and the spread portfolio of "Small minus Big" (SMB) based on the decomposed intraday return (OTC).

\section{The Role of Investor Ownership and BOJ's Announcements}

\subsection{Investor Heterogenetiy}

One sharp distinction between daytime and nighttime is that different investors have been active during different times. As individual investors are more or less active during nighttime to collect information/news or make decisions on stock selection, institutional investors have more frequent trades during daytime (Griffen, Harris, \& Topaloglu, 2003; Dasgupta, Prat, \& Verardo, 2011). Sias and Nofsinger (1999) document a strong correlation between change in investor ownership and stock return. Also, Berkman, Koch, Tuttle, and Zhang (2012) argue that the positive returns during the overnight period are more concentrated among the stocks that attracted more retail investors who drive up the opening price. Moreover, because of investor heterogeneity in beliefs, investors may have different positions in the market (Wang \& Liu, 2014). The foreign investor in the J-REIT market is a typical one that arbitrages the domestic investors. Therefore, the investor heterogeneity may help explain the asymmetric return patterns. 


\subsubsection{Sub-Period Study}

In Table 3 to Table 6, we conduct the sub-period study. The original sample is divided into pre-2006 period and post-2006 period based on the time spot of December $31^{\text {st }} 2005$. There are two reasons for the chosen time spot. First, the number of J-REITs had been very small before 2006. But after that, more qualified REITs are listed in the Japanese stock market. Second, the investor composition had a tremendous change in 2006. As shown in Figure 8, there are four types of investors in the J-REIT market, which are domestic financial institution, domestic corporation investor, domestic individual investor, and the foreign investors, constituting $100 \%$ of investor ownerships. Though Financial Institution has maintained a relatively higher proportion in REITs' investor composition, it countered a decline in the end of 2005, while foreign investor's holding percentage has increased a lot since 2006. So the investor ownership for each REIT had a structural change in 2006.

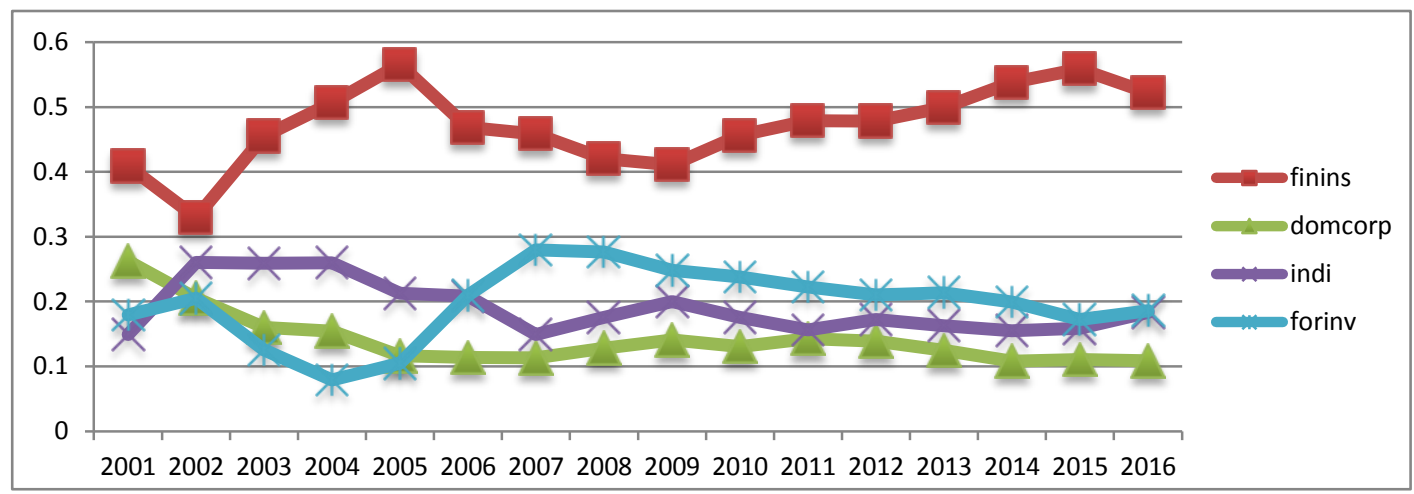

Figure 8. Average investor ownership ratio throughout sample period

Note. This figure reports the average investor ownership ratio for all REITs every year. There are four types of investors listed in the graph. "Finins" denotes the Domestic Financial Institution. "Domcorp" denotes the Domestic Corporation. "Indi" refers to as Domestic Individual Investor, while "Forinv" means Foreign Investors. The sum of four types of investor ownership will be $100 \%$ every year.

Table 3 first reports the investment-related abnormal returns before 2006. We find no significant abnormal returns during nighttime. But when adopting the intraday return, it is found a weak but significant positive investment-related abnormal return. However, after 2006, it is shown in Table 4 that during nighttime, the J-REIT market has a reversed investment effect, while in daytime the J-REIT market presents a significant positive investment effect.

Table 3. Overnight and intraday abnormal returns for investment-sorted portfolios before 2006

\begin{tabular}{|c|c|c|c|c|c|}
\hline \multicolumn{6}{|c|}{ Panel A: Daily Abnormal Return } \\
\hline \multicolumn{2}{|c|}{ AG rank } & Excess Return & CAPM Alpha & FF3 Alpha & FF5 Alpha \\
\hline \multirow[t]{4}{*}{ Low } & 1 & 0.0008 & 0.0719 & 0.0528 & 0.0471 \\
\hline & & $(2.65)$ & $(2.25)$ & $(1.62)$ & $(1.48)$ \\
\hline & 2 & 0.0006 & 0.0426 & 0.0338 & 0.0311 \\
\hline & & $(1.63)$ & $(1.17)$ & $(0.93)$ & $(0.86)$ \\
\hline \multirow[t]{2}{*}{ High } & 3 & 0.0006 & 0.0505 & 0.0347 & 0.0315 \\
\hline & & $(2.18)$ & $(1.81)$ & $(1.18)$ & $(1.09)$ \\
\hline \multirow{2}{*}{\multicolumn{2}{|c|}{ Low-High }} & 0.0002 & 0.0163 & 0.0129 & 0.0104 \\
\hline & & $(1.03)$ & $(0.73)$ & $(0.59)$ & $(0.46)$ \\
\hline \multicolumn{6}{|c|}{ Panel B: Overnight Abnormal Return } \\
\hline \multicolumn{2}{|c|}{ AG rank } & Excess Return & CAPM Alpha & FF3 Alpha & FF5 Alpha \\
\hline \multirow[t]{4}{*}{ Low } & 1 & -0.0008 & -0.0928 & -0.1012 & -0.1052 \\
\hline & & $(-3.34)$ & $(-3.94)$ & $(-4.11)$ & $(-4.38)$ \\
\hline & 2 & -0.0011 & -0.1173 & -0.1187 & -0.1222 \\
\hline & & $(-5.09)$ & $(-5.63)$ & $(-5.60)$ & $(-5.87)$ \\
\hline \multirow[t]{2}{*}{ High } & 3 & -0.0006 & -0.0690 & -0.0742 & -0.0771 \\
\hline & & $(-2.64)$ & $(-3.14)$ & $(-3.18)$ & $(-3.36)$ \\
\hline \multirow{2}{*}{\multicolumn{2}{|c|}{ Low-High }} & -0.0002 & -0.0289 & -0.0322 & -0.0333 \\
\hline & & $(-1.04)$ & $(-1.41)$ & $(-1.52)$ & $(-1.55)$ \\
\hline
\end{tabular}




\begin{tabular}{ccccc}
\hline \multicolumn{5}{c}{ Panel C: Intraday Abnormal Return } \\
\hline AG rank & Excess Return & CAPM Alpha & FF3 Alpha & FF5 Alpha \\
\hline Low 1 & 0.0017 & 0.1596 & 0.1489 & 0.1470 \\
& $(6.04)$ & $(5.83)$ & $(5.47)$ & $(5.43)$ \\
& 0.0017 & 0.1548 & 0.1474 & 0.1481 \\
& $(5.88)$ & $(5.38)$ & $(5.01)$ & $(5.00)$ \\
High & 0.0012 & 0.1144 & 0.1037 & 0.1034 \\
& $(5.04)$ & $(4.70)$ & $(4.21)$ & $(4.15)$ \\
Low-High & $0.0004^{*}$ & $0.0401^{*}$ & $0.0400^{*}$ & 0.0384 \\
& $(1.84)$ & $(1.69)$ & $(1.70)$ & $(1.62)$ \\
\hline
\end{tabular}

Note. ${ }^{*} p<0.10$. "Excess Return" is the average monthly raw returns. "CAPM Alpha" is the risk-adjusted portfolio return estimated by CAPM. "FF3 Alpha" is the risk-adjusted portfolio return estimated by Fama and French Three-Factor Model. "FF5 Alpha" is the risk-adjusted portfolio return estimated by Fama and French Five-Factor Model. T-statistics are estimated using Newey-West (1987) standard errors with 3 lags and reported in parenthesis.

Table 4. Overnight and intraday abnormal returns for investment-sorted portfolios after 2006

\begin{tabular}{|c|c|c|c|c|c|}
\hline \multicolumn{6}{|c|}{ Panel A: Daily Abnormal Return } \\
\hline \multicolumn{2}{|c|}{ AG rank } & Excess Return & CAPM Alpha & FF3 Alpha & FF5 Alpha \\
\hline \multirow[t]{4}{*}{ Low } & 1 & 0.0002 & 0.0063 & 0.0058 & 0.0068 \\
\hline & & $(0.51)$ & $(0.24)$ & $(0.22)$ & $(0.26)$ \\
\hline & 2 & 0.0001 & 0.0026 & 0.0034 & 0.0047 \\
\hline & & $(0.39)$ & $(0.09)$ & $(0.13)$ & $(0.17)$ \\
\hline \multirow[t]{2}{*}{ High } & 3 & -0.0001 & -0.0157 & -0.0152 & -0.0130 \\
\hline & & $(-0.17)$ & $(-0.48)$ & $(-0.47)$ & $(-0.40)$ \\
\hline \multirow{2}{*}{\multicolumn{2}{|c|}{ Low-High }} & 0.0002 & 0.0176 & 0.0166 & 0.0154 \\
\hline & & $(1.07)$ & $(0.84)$ & $(0.80)$ & $(0.75)$ \\
\hline \multicolumn{6}{|c|}{ Panel B: Overnight Abnormal Return } \\
\hline \multicolumn{2}{|c|}{ AG rank } & Excess Return & CAPM Alpha & FF3 Alpha & FF5 Alpha \\
\hline \multirow[t]{4}{*}{ Low } & 1 & -0.0009 & -0.0952 & -0.0953 & -0.0961 \\
\hline & & $(-4.20)$ & $(-5.08)$ & $(-5.06)$ & $(-5.00)$ \\
\hline & 2 & -0.0005 & -0.0560 & -0.0556 & -0.0562 \\
\hline & & $(-2.28)$ & $(-3.06)$ & $(-3.02)$ & $(-2.98)$ \\
\hline \multirow[t]{2}{*}{ High } & 3 & -0.0006 & -0.0630 & -0.0624 & -0.0622 \\
\hline & & $(-2.10)$ & $(-2.62)$ & $(-2.60)$ & $(-2.56)$ \\
\hline \multirow{2}{*}{\multicolumn{2}{|c|}{ Low-High }} & $-0.0003^{*}$ & $-0.0366^{* *}$ & $-0.0373 * *$ & $-0.0383 * *$ \\
\hline & & $(-1.84)$ & $(-2.10)$ & $(-2.15)$ & $(-2.23)$ \\
\hline \multicolumn{6}{|c|}{ Panel C: Intraday Abnormal Return } \\
\hline \multicolumn{2}{|c|}{ AG rank } & Excess Return & CAPM Alpha & FF3 Alpha & FF5 Alpha \\
\hline \multirow[t]{4}{*}{ Low } & 1 & 0.0010 & 0.0971 & 0.0966 & 0.0985 \\
\hline & & $(4.28)$ & $(4.15)$ & $(4.17)$ & $(4.24)$ \\
\hline & 2 & 0.0006 & 0.0542 & 0.0545 & 0.0565 \\
\hline & & $(2.39)$ & $(2.22)$ & $(2.24)$ & $(2.31)$ \\
\hline \multirow[t]{2}{*}{ High } & 3 & 0.0005 & 0.0428 & 0.0427 & 0.0448 \\
\hline & & $(2.00)$ & $(1.83)$ & $(1.84)$ & $(1.94)$ \\
\hline \multirow{2}{*}{\multicolumn{2}{|c|}{ Low-High }} & $0.0005^{* * *}$ & $0.0498^{* * *}$ & $0.0494 * * *$ & $0.0493 * * *$ \\
\hline & & (3.32) & (3.02) & (3.01) & (3.01) \\
\hline
\end{tabular}

Note. ${ }^{*} p<0.10, * * p<0.05, * * * p<0.01$. "Excess Return" is the average monthly raw returns. "CAPM Alpha" is the risk-adjusted portfolio return estimated by CAPM. "FF3 Alpha" is the risk-adjusted portfolio return estimated by Fama and French Three-Factor Model. "FF5 Alpha" is the risk-adjusted portfolio return estimated by Fama and French Five-Factor Model. T-statistics are estimated using Newey-West (1987) standard errors with 3 lags and reported in parenthesis.

When observing the size-related abnormal return. As shown in Table 5 and Table 6, we have similar findings. During the period before 2006, there is no significant size-related abnormal return during daytime but a weak reversed abnormal return in night. However, Table 6 reveals that after 2006 the J-REIT market has a very significant reversed size effect during nighttime, and follows a significant positive size effect during the daytime. 
Therefore, the asymmetric abnormal returns in daytime and nighttime are significant after 2006, a period when foreign investor increases and domestic institutional investor decreases. The analysis above preliminary confirms the hypothesis that heterogeneous investors may have different effects on the return patterns in J-REIT market.

Table 5. Overnight and intraday abnormal returns for size-sorted portfolios before 2006

\begin{tabular}{|c|c|c|c|c|c|}
\hline \multicolumn{6}{|c|}{ Panel A: Daily Abnormal Return } \\
\hline \multicolumn{2}{|c|}{ Size rank } & Excess Return & CAPM Alpha & FF3 Alpha & FF5 Alpha \\
\hline \multirow[t]{4}{*}{ Small } & 1 & 0.0005 & 0.0449 & 0.0325 & 0.0326 \\
\hline & & $(2.22)$ & $(1.86)$ & $(1.35)$ & $(1.36)$ \\
\hline & 2 & 0.0006 & 0.0515 & 0.0429 & 0.0411 \\
\hline & & $(2.42)$ & $(1.99)$ & $(1.64)$ & $(1.58)$ \\
\hline \multirow[t]{2}{*}{ Big } & 3 & 0.0006 & 0.0531 & 0.0387 & 0.0380 \\
\hline & & $(2.23)$ & $(1.88)$ & $(1.30)$ & $(1.28)$ \\
\hline \multirow{2}{*}{\multicolumn{2}{|c|}{ Small-Big }} & -0.0001 & -0.0139 & -0.0121 & -0.0112 \\
\hline & & $(-0.34)$ & $(-0.53)$ & $(-0.45)$ & $(-0.42)$ \\
\hline \multicolumn{6}{|c|}{ Panel B: Overnight Abnormal Return } \\
\hline \multicolumn{2}{|c|}{ Size rank } & Excess Return & CAPM Alpha & FF3 Alpha & FF5 Alpha \\
\hline \multirow[t]{4}{*}{ Small } & 1 & -0.0005 & -0.0613 & -0.0644 & -0.0651 \\
\hline & & $(-3.33)$ & $(-3.73)$ & $(-3.89)$ & $(-3.90)$ \\
\hline & 2 & -0.0010 & -0.1051 & -0.1064 & -0.1077 \\
\hline & & $(-4.84)$ & $(-5.33)$ & $(-5.21)$ & $(-5.25)$ \\
\hline \multirow[t]{2}{*}{ Big } & 3 & -0.0002 & -0.0240 & -0.0303 & -0.0309 \\
\hline & & $(-0.80)$ & $(-1.25)$ & $(-1.50)$ & $(-1.53)$ \\
\hline \multirow{2}{*}{\multicolumn{2}{|c|}{ Small-Big }} & $-0.0004^{*}$ & $-0.0431 * *$ & $-0.0399 *$ & $-0.0400 *$ \\
\hline & & $(-1.88)$ & $(-2.09)$ & $(-1.86)$ & $(-1.86)$ \\
\hline \multicolumn{6}{|c|}{ Panel C: Intraday Abnormal Return } \\
\hline \multicolumn{2}{|c|}{ Size rank } & Excess Return & CAPM Alpha & FF3 Alpha & FF5 Alpha \\
\hline \multirow[t]{4}{*}{ Small } & 1 & 0.0011 & 0.1005 & 0.0910 & 0.0918 \\
\hline & & $(5.53)$ & $(5.16)$ & $(4.77)$ & $(4.83)$ \\
\hline & 2 & 0.0016 & 0.1508 & 0.1434 & 0.1430 \\
\hline & & $(7.51)$ & $(7.16)$ & $(6.68)$ & $(6.66)$ \\
\hline \multirow[t]{2}{*}{ Big } & 3 & 0.0008 & 0.0713 & 0.0632 & 0.0630 \\
\hline & & $(3.31)$ & $(2.96)$ & $(2.56)$ & $(2.55)$ \\
\hline \multirow{2}{*}{\multicolumn{2}{|c|}{ Small-Big }} & 0.0003 & 0.0234 & 0.0220 & 0.0230 \\
\hline & & $(1.21)$ & $(0.94)$ & $(0.88)$ & $(0.91)$ \\
\hline
\end{tabular}

Note. $* p<0.10, * * p<0.05$. "Excess Return" is the average monthly raw returns. "CAPM Alpha" is the risk-adjusted portfolio return estimated by CAPM. "FF3 Alpha" is the risk-adjusted portfolio return estimated by Fama and French Three-Factor Model. "FF5 Alpha" is the risk-adjusted portfolio return estimated by Fama and French Five-Factor Model. T-statistics are estimated using Newey-West (1987) standard errors with 3 lags and reported in parenthesis.

Table 6. Overnight and intraday abnormal returns for size-sorted portfolios after 2006

\begin{tabular}{|c|c|c|c|c|c|}
\hline \multicolumn{6}{|c|}{ Panel A: Daily Abnormal Return } \\
\hline \multicolumn{2}{|c|}{ Size rank } & Excess Return & CAPM Alpha & FF3 Alpha & FF5 Alpha \\
\hline \multirow[t]{4}{*}{ Small } & 1 & 0.0000 & -0.0052 & -0.0058 & -0.0050 \\
\hline & & $(0.11)$ & $(-0.17)$ & $(-0.19)$ & $(-0.16)$ \\
\hline & 2 & 0.0001 & 0.0001 & -0.0002 & 0.0008 \\
\hline & & $(0.28)$ & $(0.00)$ & $(-0.01)$ & $(0.03)$ \\
\hline \multirow[t]{2}{*}{ Big } & 3 & 0.0000 & -0.0057 & -0.0040 & -0.0014 \\
\hline & & $(0.13)$ & $(-0.20)$ & $(-0.14)$ & $(-0.05)$ \\
\hline \multirow{2}{*}{\multicolumn{2}{|c|}{ Small-Big }} & -0.0000 & -0.0040 & -0.0063 & -0.0080 \\
\hline & & $(-0.02)$ & $(-0.16)$ & $(-0.26)$ & $(-0.34)$ \\
\hline
\end{tabular}




\begin{tabular}{|c|c|c|c|c|c|}
\hline \multicolumn{6}{|c|}{ Panel B: Overnight Abnormal Return } \\
\hline \multicolumn{2}{|c|}{ Size rank } & Excess Return & CAPM Alpha & FF3 Alpha & FF5 Alpha \\
\hline \multirow[t]{4}{*}{ Small } & 1 & -0.0009 & -0.0989 & -0.0993 & -0.1005 \\
\hline & & $(-4.27)$ & $(-5.04)$ & $(-5.05)$ & $(-5.02)$ \\
\hline & 2 & -0.0006 & -0.0673 & -0.0670 & -0.0673 \\
\hline & & $(-2.74)$ & $(-3.50)$ & $(-3.48)$ & $(-3.41)$ \\
\hline \multirow[t]{2}{*}{ Big } & 3 & -0.0004 & -0.0453 & -0.0445 & -0.0444 \\
\hline & & $(-1.75)$ & $(-2.44)$ & $(-2.39)$ & $(-2.33)$ \\
\hline \multirow{2}{*}{\multicolumn{2}{|c|}{ Small-Big }} & $-0.0005 * * *$ & $-0.0580^{* * *}$ & $-0.0593 * * *$ & $-0.0605 * * *$ \\
\hline & & $(-3.47)$ & $(-3.67)$ & $(-3.77)$ & $(-3.84)$ \\
\hline \multicolumn{6}{|c|}{ Panel C: Intraday Abnormal Return } \\
\hline \multicolumn{2}{|c|}{ Size rank } & Excess Return & CAPM Alpha & FF3 Alpha & FF5 Alpha \\
\hline \multirow[t]{4}{*}{ Small } & 1 & 0.0010 & 0.0893 & 0.0891 & 0.0910 \\
\hline & & $(3.94)$ & $(3.84)$ & $(3.85)$ & $(3.95)$ \\
\hline & 2 & 0.0007 & 0.0630 & 0.0624 & 0.0637 \\
\hline & & $(2.60)$ & $(2.44)$ & $(2.43)$ & $(2.48)$ \\
\hline \multirow[t]{2}{*}{ Big } & 3 & 0.0004 & 0.0352 & 0.0361 & 0.0385 \\
\hline & & $(1.55)$ & $(1.38)$ & $(1.41)$ & $(1.51)$ \\
\hline \multirow{2}{*}{\multicolumn{2}{|c|}{ Small-Big }} & $0.0005^{* * *} *$ & $0.0496 * *$ & $0.0486^{* *}$ & $0.0481 * *$ \\
\hline & & $(2.71)$ & $(2.48)$ & $(2.44)$ & $(2.40)$ \\
\hline
\end{tabular}

Note. ** $p<0.05, * * * p<0.01$. "Excess Return" is the average monthly raw returns. "CAPM Alpha" is the risk-adjusted portfolio return estimated by CAPM. "FF3 Alpha" is the risk-adjusted portfolio return estimated by Fama and French Three-Factor Model. "FF5 Alpha" is the risk-adjusted portfolio return estimated by Fama and French Five-Factor Model. T-statistics are estimated using Newey-West (1987) standard errors with 3 lags and reported in parenthesis.

\subsubsection{Univariate Sorting}

To approach the kernel that has caused the asymmetric patterns in J-REIT decomposed daily return, we further investigate the relation between investor ownership and overnight-intraday abnormal return.

Table 7 first investigates the role of foreign investor. Based on the holdings of foreign investor, all REITs are ranked and allocated in the end of March every year. Three portfolios are equal-weighted formed and held for one year. The spread portfolio of "Low minus High" (LMH) is formed and to capture the return dispersions between the low-foreigner holding group and the high-foreigner holding group. The raw excess returns as well as risk-adjusted returns are reported in the table with their t-statistics listed in the parenthesis. As shown in Table 7, during the period after 2006, the total daily return is not significant, but the overnight return has very significant pattern that firms with lower foreign investor holdings will have higher average returns. On the contrary, during daytime, firms with lower foreign investor holdings will have lower average returns. We also conduct the study in full period and pre-2006 period, but there is no significant result. Because the proportion of foreign investor in the J-REIT market has dramatically increased since 2006, the findings above confirm the hypothesis that foreign investors started to affect the J-REIT market only after 2006.

Table 7. Post-2006 abnormal returns sorted by foreign investor

\begin{tabular}{|c|c|c|c|c|c|}
\hline \multicolumn{6}{|c|}{ Panel A: Daily Abnormal Return } \\
\hline \multicolumn{2}{|c|}{ IO rank } & Excess Return & CAPM Alpha & FF3 Alpha & FF5 Alpha \\
\hline \multirow[t]{4}{*}{ Low } & 1 & 0.0001 & -0.0006 & -0.0005 & 0.0006 \\
\hline & & $(0.29)$ & $(-0.02)$ & $(-0.02)$ & $(0.02)$ \\
\hline & 2 & 0.0000 & -0.0086 & -0.0086 & -0.0069 \\
\hline & & $(0.03)$ & $(-0.28)$ & $(-0.28)$ & $(-0.23)$ \\
\hline \multirow[t]{2}{*}{ High } & 3 & 0.0001 & -0.0000 & 0.0006 & 0.0023 \\
\hline & & $(0.26)$ & $(-0.00)$ & $(0.02)$ & $(0.07)$ \\
\hline \multirow{2}{*}{\multicolumn{2}{|c|}{ Low-High }} & -0.0000 & -0.0050 & -0.0056 & -0.0062 \\
\hline & & $(-0.04)$ & $(-0.24)$ & $(-0.27)$ & $(-0.30)$ \\
\hline
\end{tabular}




\begin{tabular}{|c|c|c|c|c|c|}
\hline \multicolumn{6}{|c|}{ Panel B: Overnight Abnormal Return } \\
\hline \multicolumn{2}{|c|}{ IO rank } & Excess Return & CAPM Alpha & FF3 Alpha & FF5 Alpha \\
\hline \multirow[t]{4}{*}{ Low } & 1 & -0.0004 & -0.0471 & -0.0470 & -0.0474 \\
\hline & & $(-2.10)$ & $(-2.86)$ & $(-2.84)$ & $(-2.80)$ \\
\hline & 2 & -0.0007 & -0.0803 & -0.0798 & -0.0805 \\
\hline & & $(-3.33)$ & $(-4.15)$ & $(-4.11)$ & $(-4.08)$ \\
\hline \multirow[t]{2}{*}{ High } & 3 & -0.0008 & -0.0854 & -0.0852 & -0.0856 \\
\hline & & $(-3.11)$ & $(-3.77)$ & $(-3.75)$ & $(-3.68)$ \\
\hline \multirow{2}{*}{\multicolumn{2}{|c|}{ Low-High }} & $0.0004 * *$ & $0.0338 * *$ & $0.0338 * *$ & $0.0338 * *$ \\
\hline & & $(2.40)$ & $(2.15)$ & $(2.16)$ & $(2.16)$ \\
\hline \multicolumn{6}{|c|}{ Panel C: Intraday Abnormal Return } \\
\hline \multicolumn{2}{|c|}{ IO rank } & Excess Return & CAPM Alpha & FF3 Alpha & FF5 Alpha \\
\hline \multirow[t]{4}{*}{ Low } & 1 & 0.0005 & 0.0421 & 0.0420 & 0.0435 \\
\hline & & $(1.97)$ & $(1.78)$ & $(1.78)$ & $(1.85)$ \\
\hline & 2 & 0.0007 & 0.0672 & 0.0668 & 0.0691 \\
\hline & & $(2.77)$ & $(2.64)$ & $(2.63)$ & $(2.72)$ \\
\hline \multirow[t]{2}{*}{ High } & 3 & 0.0009 & 0.0809 & 0.0814 & 0.0835 \\
\hline & & $(3.45)$ & (3.33) & $(3.36)$ & $(3.46)$ \\
\hline \multirow{2}{*}{\multicolumn{2}{|c|}{ Low-High }} & $-0.0004 * *$ & $-0.0432 * * *$ & $-0.0438 * * *$ & $-0.0444 * * *$ \\
\hline & & $(-2.36)$ & $(-2.62)$ & $(-2.67)$ & $(-2.71)$ \\
\hline
\end{tabular}

Note. $* * p<0.05, * * * p<0.01$. The rank variable: Investor Ownership (IO) refers to Foreign Investor's holdings. "Excess Return" is the average raw returns. "CAPM Alpha" is the risk-adjusted portfolio return estimated by CAPM. "FF3 Alpha" is the risk-adjusted portfolio return estimated by Fama and French Three-Factor Model. "FF5 Alpha" is the risk-adjusted portfolio return estimated by Fama and French Five-Factor Model. T-statistics are estimated using Newey-West (1987) standard errors with 3 lags and reported in parenthesis.

Table 8 reports the relation between decomposed daily return and domestic individual investor for the post-2006 period. Aligning with the methodology stated above, all the REITs are allocated into three portfolios and a spread portfolio is constructed based on their last year individual investor holdings. According to the results, though investigation on the total daily return still provides no significant results, it is found that the firms with lower individual investor ownership level, their overnight returns are higher. And vice versa, firms that have higher level of individual investor ownership will have smaller overnight returns. The asymmetric pattern occurs in the daytime. When the holdings of individual investor are larger, the intraday return is also higher.

Table 8. Post-2006 abnormal return sorted by individual investor

\begin{tabular}{|c|c|c|c|c|c|}
\hline \multicolumn{6}{|c|}{ Panel A: Daily Abnormal Return } \\
\hline \multicolumn{2}{|c|}{ IO rank } & Excess Return & CAPM Alpha & FF3 Alpha & FF5 Alpha \\
\hline \multirow[t]{4}{*}{ Low } & 1 & 0.0000 & -0.0058 & -0.0050 & -0.0028 \\
\hline & & $(0.12)$ & $(-0.21)$ & $(-0.18)$ & $(-0.10)$ \\
\hline & 2 & 0.0002 & 0.0114 & 0.0118 & 0.0131 \\
\hline & & $(0.63)$ & $(0.40)$ & $(0.41)$ & $(0.45)$ \\
\hline \multirow[t]{2}{*}{ High } & 3 & -0.0001 & -0.0166 & -0.0175 & -0.0170 \\
\hline & & $(-0.19)$ & $(-0.48)$ & $(-0.51)$ & $(-0.49)$ \\
\hline \multirow{2}{*}{\multicolumn{2}{|c|}{ Low-High }} & 0.0001 & 0.0063 & 0.0081 & 0.0097 \\
\hline & & $(0.47)$ & $(0.27)$ & $(0.35)$ & $(0.42)$ \\
\hline \multicolumn{6}{|c|}{ Panel B: Overnight Abnormal Return } \\
\hline \multicolumn{2}{|c|}{ IO rank } & Excess Return & CAPM Alpha & FF3 Alpha & FF5 Alpha \\
\hline \multirow[t]{4}{*}{ Low } & 1 & -0.0003 & -0.0411 & -0.0405 & -0.0403 \\
\hline & & $(-1.60)$ & $(-2.28)$ & $(-2.23)$ & $(-2.17)$ \\
\hline & 2 & -0.0007 & -0.0737 & -0.0735 & -0.0744 \\
\hline & & & $(-4.04)$ & $(-4.00)$ & $(-3.98)$ \\
\hline \multirow[t]{2}{*}{ High } & 3 & -0.0010 & -0.1109 & -0.1110 & -0.1121 \\
\hline & & $(-4.12)$ & $(-4.77)$ & $(-4.77)$ & $(-4.73)$ \\
\hline \multirow{2}{*}{\multicolumn{2}{|c|}{ Low-High }} & $0.0007 * * *$ & $0.0653 * * *$ & $0.0660 * * *$ & $0.0674 * * *$ \\
\hline & & (4.17) & (3.88) & (3.94) & $(4.00)$ \\
\hline
\end{tabular}




\begin{tabular}{|c|c|c|c|c|c|}
\hline \multicolumn{6}{|c|}{ Panel C: Intraday Abnormal Return } \\
\hline \multicolumn{2}{|c|}{ IO rank } & Excess Return & CAPM Alpha & FF3 Alpha & FF5 Alpha \\
\hline \multirow[t]{4}{*}{ Low } & 1 & 0.0004 & 0.0308 & 0.0311 & 0.0330 \\
\hline & & $(1.43)$ & $(1.24)$ & $(1.25)$ & $(1.33)$ \\
\hline & 2 & 0.0009 & 0.0806 & 0.0808 & 0.0830 \\
\hline & & $(3.35)$ & $(3.23)$ & $(3.24)$ & $(3.34)$ \\
\hline \multirow{2}{*}{\multicolumn{2}{|c|}{ High }} & 0.0010 & 0.0899 & 0.0890 & 0.0906 \\
\hline & & $(3.73)$ & $(3.63)$ & $(3.62)$ & $(3.70)$ \\
\hline \multirow{2}{*}{\multicolumn{2}{|c|}{ Low-High }} & $-0.0006^{* * *}$ & $-0.0635 * * *$ & $-0.0623 * * *$ & $-0.0621 * * *$ \\
\hline & & $(-3.29)$ & $(-3.54)$ & $(-3.49)$ & $(-3.46)$ \\
\hline
\end{tabular}

Note. ${ }^{* * *} p<0.01$. The rank variable: Investor ownership (IO) refers to Individual Investor's holdings. "Excess Return" is the average raw returns. "CAPM Alpha" is the risk-adjusted portfolio return estimated by CAPM. "FF3 Alpha" is the risk-adjusted portfolio return estimated by Fama and French Three-Factor Model. "FF5 Alpha" is the risk-adjusted portfolio return estimated by Fama and French Five-Factor Model. T-statistics are estimated using Newey-West (1987) standard errors with 3 lags and reported in parenthesis.

According to the hypothesis, financial institution usually trades against foreign investor and individual investor. Table 9 reports the investigation on the relation between daily return and financial institution. Similarly, when observing the total daily return, we find no significant return patterns. However, when observing the decomposed daily return, we notice that firms that have lower holdings by the financial institution will have smaller overnight return but larger intraday return. Vice versa, firms that have higher holdings by the financial institution will have larger overnight return but smaller intraday return. The asymmetric return patterns are significant at $99 \%$ confidence intervals.

Table 9. Post-2006 abnormal return sorted by financial institution

\begin{tabular}{|c|c|c|c|c|c|}
\hline \multicolumn{6}{|c|}{ Panel A: Daily Abnormal Return } \\
\hline \multicolumn{2}{|c|}{ IO rank } & Excess Return & CAPM Alpha & FF3 Alpha & FF5 Alpha \\
\hline \multirow[t]{4}{*}{ Low } & 1 & 0.0001 & 0.0004 & 0.0000 & 0.0004 \\
\hline & & $(0.24)$ & $(0.01)$ & $(0.00)$ & $(0.01)$ \\
\hline & 2 & 0.0000 & -0.0062 & -0.0057 & -0.0035 \\
\hline & & $(0.10)$ & $(-0.20)$ & $(-0.18)$ & $(-0.11)$ \\
\hline \multirow[t]{2}{*}{ High } & 3 & 0.0000 & -0.0059 & -0.0054 & -0.0038 \\
\hline & & $(0.12)$ & $(-0.22)$ & $(-0.20)$ & $(-0.14)$ \\
\hline \multirow{2}{*}{\multicolumn{2}{|c|}{ Low-High }} & 0.0001 & 0.0018 & 0.0010 & -0.0003 \\
\hline & & $(0.21)$ & $(0.07)$ & $(0.04)$ & $(-0.01)$ \\
\hline \multicolumn{6}{|c|}{ Panel B: Overnight Abnormal Return } \\
\hline \multicolumn{2}{|c|}{ IO rank } & Excess Return & CAPM Alpha & FF3 Alpha & FF5 Alpha \\
\hline \multirow[t]{4}{*}{ Low } & 1 & -0.0011 & -0.1219 & -0.1222 & -0.1234 \\
\hline & & $(-4.51)$ & $(-5.15)$ & $(-5.17)$ & $(-5.12)$ \\
\hline & 2 & -0.0005 & -0.0583 & -0.0580 & -0.0580 \\
\hline & & $(-2.28)$ & $(-2.98)$ & $(-2.95)$ & $(-2.88)$ \\
\hline \multirow[t]{2}{*}{ High } & 3 & -0.0004 & -0.0438 & -0.0432 & -0.0435 \\
\hline & & $(-1.81)$ & $(-2.54)$ & $(-2.49)$ & $(-2.46)$ \\
\hline \multirow{2}{*}{\multicolumn{2}{|c|}{ Low-High }} & $-0.0008 * * *$ & $-0.0825^{* * * *}$ & $-0.0835^{* * *}$ & $-0.0844 * * *$ \\
\hline & & $(-4.23)$ & $(-4.43)$ & $(-4.51)$ & $(-4.56)$ \\
\hline & & & Intraday Abnor & & \\
\hline \multicolumn{2}{|c|}{ IO rank } & Excess Return & CAPM Alpha & FF3 Alpha & FF5 Alpha \\
\hline \multirow[t]{4}{*}{ Low } & 1 & 0.0012 & 0.1179 & 0.1178 & 0.1194 \\
\hline & & $(4.87)$ & $(4.80)$ & $(4.82)$ & $(4.90)$ \\
\hline & 2 & 0.0005 & 0.0477 & 0.0479 & 0.0500 \\
\hline & & $(2.02)$ & $(1.86)$ & $(1.88)$ & $(1.97)$ \\
\hline \multirow[t]{2}{*}{ High } & 3 & 0.0004 & 0.0335 & 0.0333 & 0.0353 \\
\hline & & (1.55) & (1.36) & (1.35) & (1.43) \\
\hline \multirow{2}{*}{\multicolumn{2}{|c|}{ Low-High }} & $0.0008 * * *$ & $0.0799 * * *$ & $0.0801 * * *$ & $0.0796^{* * *}$ \\
\hline & & (4.22) & (3.98) & $(4.00)$ & (3.98) \\
\hline
\end{tabular}

Note. *** $p<0.01$. The rank variable: Investor ownership (IO) refers to Financial Institution's holdings. "Excess Return" is the average raw returns. "CAPM Alpha" is the risk-adjusted portfolio return estimated by CAPM. "FF3 Alpha" is the risk-adjusted portfolio return estimated by Fama and French Three-Factor Model. "FF5 Alpha" is the risk-adjusted portfolio return estimated by Fama and French Five-Factor Model. T-statistics are estimated using Newey-West (1987) standard errors with 3 lags and reported in parenthesis. 
Finally, we investigate the relation between REITs daily return and domestic corporation ownership. It is shown in Table 10 that the holdings of domestic corporation have very weak effect on the overnight return during the period of 2006-2016 and no significant effect for the full-period sample data.

Table 10. Post-2006 abnormal return sorted by domestic corporation

\begin{tabular}{|c|c|c|c|c|c|}
\hline \multicolumn{6}{|c|}{ Panel A: Daily Abnormal Return } \\
\hline \multicolumn{2}{|c|}{ IO rank } & Excess Return & CAPM Alpha & FF3 Alpha & FF5 Alpha \\
\hline \multirow[t]{4}{*}{ Low } & 1 & 0.0000 & -0.0065 & -0.0057 & -0.0039 \\
\hline & & $(0.10)$ & $(-0.23)$ & $(-0.20)$ & $(-0.14)$ \\
\hline & 2 & -0.0000 & -0.0115 & -0.0118 & -0.0105 \\
\hline & & $(-0.06)$ & $(-0.38)$ & $(-0.39)$ & $(-0.34)$ \\
\hline \multirow[t]{2}{*}{ High } & 3 & 0.0002 & 0.0093 & 0.0096 & 0.0110 \\
\hline & & $(0.58)$ & $(0.33)$ & $(0.34)$ & $(0.39)$ \\
\hline \multirow{2}{*}{\multicolumn{2}{|c|}{ Low-High }} & -0.0002 & -0.0202 & -0.0197 & -0.0193 \\
\hline & & $(-1.07)$ & $(-1.40)$ & $(-1.37)$ & $(-1.34)$ \\
\hline \multicolumn{6}{|c|}{ Panel B: Overnight Abnormal Return } \\
\hline \multicolumn{2}{|c|}{ IO rank } & Excess Return & CAPM Alpha & FF3 Alpha & FF5 Alpha \\
\hline \multirow[t]{4}{*}{ Low } & 1 & -0.0008 & -0.0888 & -0.0883 & -0.0885 \\
\hline & & $(-3.71)$ & $(-4.60)$ & $(-4.56)$ & $(-4.48)$ \\
\hline & 2 & -0.0004 & -0.0477 & -0.0475 & -0.0481 \\
\hline & & $(-1.85)$ & $(-2.47)$ & $(-2.45)$ & $(-2.42)$ \\
\hline \multirow[t]{2}{*}{ High } & 3 & -0.0006 & -0.0728 & -0.0726 & -0.0731 \\
\hline & & $(-3.27)$ & $(-4.14)$ & $(-4.12)$ & $(-4.06)$ \\
\hline \multirow{2}{*}{\multicolumn{2}{|c|}{ Low-High }} & -0.0002 & $-0.0205^{*}$ & $-0.0201 *$ & $-0.0199 *$ \\
\hline & & $(-1.37)$ & $(-1.79)$ & $(-1.76)$ & $(-1.73)$ \\
\hline \multicolumn{6}{|c|}{ Panel C: Intraday Abnormal Return } \\
\hline \multicolumn{2}{|c|}{ IO rank } & Excess Return & CAPM Alpha & FF3 Alpha & FF5 Alpha \\
\hline \multirow[t]{4}{*}{ Low } & 1 & 0.0008 & 0.0779 & 0.0781 & 0.0802 \\
\hline & & $(3.41)$ & $(3.29)$ & $(3.30)$ & $(3.38)$ \\
\hline & 2 & 0.0004 & 0.0317 & 0.0312 & 0.0332 \\
\hline & & $(1.49)$ & $(1.30)$ & $(1.28)$ & $(1.37)$ \\
\hline \multirow[t]{2}{*}{ High } & 3 & 0.0008 & 0.0776 & 0.0778 & 0.0796 \\
\hline & & $(3.23)$ & $(3.11)$ & $(3.13)$ & $(3.21)$ \\
\hline \multirow{2}{*}{\multicolumn{2}{|c|}{ Low-High }} & 0.0000 & -0.0042 & -0.0041 & -0.0039 \\
\hline & & $(0.01)$ & $(-0.29)$ & $(-0.28)$ & $(-0.26)$ \\
\hline
\end{tabular}

Note. ${ }^{*} p<0.10$. The rank variable: Investor ownership (IO) refers to Domestic Corporation's holdings. "Excess Return" is the average raw returns. "CAPM Alpha" is the risk-adjusted portfolio return estimated by CAPM. "FF3 Alpha" is the risk-adjusted portfolio return estimated by Fama and French Three-Factor Model. "FF5 Alpha" is the risk-adjusted portfolio return estimated by Fama and French Five-Factor Model. T-statistics are estimated using Newey-West (1987) standard errors with 3 lags and reported in parenthesis.

Based on the analysis conducted in this section, it is found that foreign investor and individual investor have similar effects on J-REIT decomposed daily return. Firms that have higher ownership of either foreign investor or individual investor will have smaller overnight returns but larger intraday returns. Also, foreign investor has started to affect J-REIT market since 2006, in which the J-REITs holdings of foreign investor increased a lot. Meanwhile, results reveal that firms that have higher ownership of financial institution investor will have larger overnight returns but smaller intraday returns, which is consistent with the investor hetergeneity hypothesis that in J-REIT market, financial institution trades against foreign investor and individual investor. But for domestic corporation investor, its ownership level has little effect on J-REIT decomposed daily return.

\subsection{Information Surprise}

As Lou, Polk, and Skouras (2015) and Lucca and Moench (2015) pointed, the macroeconomic announcement that has been relevant to the whole market may have potential to reveal the risk dispersions across the announcement periods for certain cross-sectional anomalies. So in this section, event study is adopted to inspect whether J-REIT market makes quick respond to general macroeconomic news, such as the announcement from the meeting of the Bank of Japan (BOJ), and how long it takes for the market to digest the news. Among the BOJ 
announcements, all the news is released during the afternoon.

Table 11 presents the overnight (CTO) and intraday (OTC) decomposed daily return as well as the total daily (CTC) return for AG-based and size-based spread portfolios before, on, and after the day of BOJ announcements. It is noticed in both cases, overnight return $\left(\mathrm{CTO}_{t}\right)$ and the total daily return $\left(\mathrm{CTC}_{\mathrm{t}}\right)$ of the event day (when announcements are released) are significant, which means the J-REIT market makes a quick and strong respond to the macro news released by BOJ. Specifically, BOJ's announcements will strengthen the intraday investment effect, because abnormal return on long-short portfolio based on AG-strategy is positive. On the contrary, BOJ's announcements reverse the intraday size effect, because intraday abnormal return on the size-based spread portfolio is negative. However, BOJ announcements have a continuous effect on size-related abnormal return, since the overnight return $\left(\mathrm{CTO}_{\mathrm{t}+1}\right)$ and total daily return $\left(\mathrm{CTC}_{\mathrm{t}+1}\right)$ of the post-event day are still significant. So the BOJ news strengthens the overnight size effect. To be noticed, BOJ's announcements have no effect on the pre-event day but only affect the intraday return of the announcement day and the overnight return after the announcement day.

Table 11. Abnormal returns around BOJ announcements

\begin{tabular}{cccccccccc}
\hline & $\mathrm{CTO}_{\mathrm{t}-1}$ & $\mathrm{OTC}_{\mathrm{t}-1}$ & $\mathrm{CTC}_{\mathrm{t}-1}$ & $\mathrm{CTO}_{\mathrm{t}}$ & $\mathrm{OTC}_{\mathrm{t}}$ & $\mathrm{CTC}_{\mathrm{t}}$ & $\mathrm{CTO}_{\mathrm{t}+1}$ & $\mathrm{OTC}_{\mathrm{t}+1}$ & $\mathrm{CTC}_{\mathrm{t}+1}$ \\
\hline AG ret. & -0.002 & -0.002 & -0.004 & 0.001 & $0.005^{* *}$ & $0.006^{* * *}$ & -0.003 & -0.001 & -0.004 \\
t-value & -0.99 & -0.964 & -1.022 & 0.714 & 2.18 & 3.867 & -0.747 & -0.166 & -1.677 \\
Size ret. & 0.005 & 0 & 0.005 & -0.001 & $-0.008 * *$ & $-0.008 * *$ & $-0.008 * *$ & 0 & $-0.008^{* *}$ \\
t-value & 1.306 & -0.045 & 1.754 & -0.346 & -1.813 & -1.959 & -2.228 & 0.027 & -2.171 \\
\hline
\end{tabular}

Note. $* * \mathrm{p}<0.05, * * * \mathrm{p}<0.01$. This table reports the average daily returns (CTC) and decomposed returns (CTO and OTC) for the spread portfolios based on AG strategy and Size strategy before, on and after the event day. Event time is the day when BOJ releases important announcements.

To sum up, BOJ's announcement will intensify the intraday investment-related abnormal return as well as the overnight size-related abnormal return. Therefore, the asymmetric overnight and intraday abnormal return patterns are strengthened under the information surprises.

\section{Conclusion}

This study proposes a novel decomposition of J-REIT daily returns into overnight and intraday returns and examines the cross-sectional abnormal returns in the daytime and nighttime. Ample evidence reveals an overnight-intraday anomaly that both the investment effect and the size effect occur intraday, but the reversed investment effect and the reversed size effect occur overnight.

Furthermore, we investigate the role of investor heterogeneity in generating abnormal returns on J-REITs. After 2006, when the J-REIT market comprised more foreign investors, along with more domestic individual investors, the overnight-intraday anomaly is more significant. However, before 2006, when there were few foreign investors in the market, we find no significant return patterns. Meanwhile, unlike domestic institutional investors, the number of foreign as well as individual investors increases with the rise in intraday returns and decreases with the rise in overnight returns. Therefore, both foreign investors and individual investors trade against the domestic institutional investors, and strengthen the positive abnormal returns in the daytime and negative abnormal returns in the nighttime.

Moreover, our study discusses whether the information surprise brought by the Bank of Japan (BOJ) affects the J-REIT stock price changes. Results show that the J-REIT market responds quickly and strongly to the macroeconomic news released by the BOJ. The response is so quick that the information surprise lasts for only one day (for investment effect) to two days (for size effect). Furthermore, the overnight-intraday anomaly in the J-REIT market is intensified by the BOJ's announcements.

\section{Acknowledgments}

This work is supported by JSPS KAKENHI Grant Number: JP26504015. We thank Charles Leung as a discussant of an earlier version of the paper in the 2017 Asian Real Estate Society International Conference. We also acknowledge Takashi Shibata to provide part of the data.

\section{References}

Banz, R. (1981). The relationship between return and market value of common stocks. Journal of Financial Economics, 9(1), 3-18. https://doi.org/10.1016/0304-405X(81)90018-0 
Berkman, H., Koch, P., Tuttle, L., \& Zhang, Y. (2012). Paying attention: overnight returns and the hidden cost of buying at the open. Journal of Financial and Quantitative Analysis, 47(4), 715-741. https://doi.org/10.1017/S0022109012000270

Branch, B., \& Ma, A. (2012). Overnight return, the invisible hand behind intraday returns? Journal of Applied Finance, 22(2). Retrieved from https://ssrn.com/abstract=2689719

Chan, K. C., \& Chen, N. (1991). Structural and return characteristics of small and large firms. The Journal of Finance, 46, 1467-1484. https://doi.org/10.1111/j.1540-6261.1991.tb04626.x

Chan, K. C., Chen, N., \& Hsieh, D. A. (1985). An exploratory investigation of the firm size effect. Journal of Financial Economics, 14, 451-471. https://doi.org/10.1016/0304-405X(85)90008-X

Chen, J. (2017). What explains the investment anomaly in the Chinese stock market? Nankai Business Review International, 8(4), 495-520. https://doi.org/10.1108/NBRI-05-2016-0021

Cooper, I., \& Priestley, R. (2011). Real investment and risk dynamics. Journal of Financial Economics, 101, 182-205. https://doi.org/10.1016/j.jfineco.2011.02.002

Cooper, M., Downs, D., \& Patterson, G. (1999). Real estate securities and a filter-based, short-term trading strategy. Journal of Real Estate Research, 18(2), 313-333.

Cooper, M., Downs, D., \& Patterson, G. (2000). Asymmetric information and the predictability of real estate returns. Journal of Real Estate Finance and Economics, 20(2), 225-244. https://doi.org/10.1023/A:1007833506453

Cooper, M., Gulen, H., \& Schill, M. (2008). Asset growth and the cross-section of stock returns. The Journal of Finance, 68, 1609-1651. https://doi.org/10.1111/j.1540-6261.2008.01370.x

Dasgupta, A., Prat, A., \& Verardo, M. (2011). Institutional trade persistence and long-term equity returns. Journal of Finance, 66, 635-653. https://doi.org/10.1111/j.1540-6261.2010.01644.x

Fama, E., \& French, K. (1992). The cross-section of expected stock returns. The Journal of Finance, 47, 427-465. https://doi.org/10.1111/j.1540-6261.1992.tb04398.x

Fama, E., \& French, K. (1993). Common risk factors in the returns on stocks and bonds. Journal of Financial Economics, 33, 3-56. https://doi.org/10.1016/0304-405X(93)90023-5

Fama, E., \& French, K. (2006). Dissecting anomalies. The Journal of Finance, 63, 1653-1678. https://doi.org/10.1111/j.1540-6261.2008.01371.x

Fama, E., \& French, K. (2015). A five-factor asset pricing model. Journal of Financial Economics, 116, 1-22. https://doi.org/10.1016/j.jfineco.2014.10.010

Fama, E., \& French, K. (2016). Dissecting anomalies with a five-factor model. The Review of Financial Studies, 29, 69-103. https://doi.org/10.1093/rfs/hhv043

Gray, P., \& Johnson, J. (2011). The relationship between asset growth and the cross-section of stock returns. Journal of Banking \& Finance, 35, 670-680. https://doi.org/10.1016/j.jbankfin.2010.06.005

Griffen, J., Harris, J., \& Topaloglu, S. (2003). The dynamics of institutional and individual trading. Journal of Finance, 58, 2285-2320. https://doi.org/10.1046/j.1540-6261.2003.00606.x

Ito, T. (2016). The reaction of the Japanese REIT market to stock prices and interest rates: A comparison of the periods before and after Abenomics. International Journal of Monetary Economics and Finance, 9(4), 319-329. https://doi.org/10.1504/IJMEF.2016.080076

Jegadeesh, N., \& Titman, S. (1993). Returns to buying winners and selling losers: Implications for stock market efficiency. Journal of Finance, 48, 65-92. https://doi.org/10.1111/j.1540-6261.1993.tb04702.x

Li, R., \& Chau, K. W. (2016). Econometric Analyses of International Housing Markets. London: Routledge.

Liao, H., \& Mei, J. (1998). Risk characteristics of real estate related securities: An extension of Liu and Mei (1992). Journal of Real Estate Research, 16(3), 279-290. Retrieved from: http://pages.jh.edu/jrer/papers/pdf/past/vol16n03/v16p279.pdf

Liu, C., \& Mei, J. (1992). The predictability of returns on equity REITs and their co-movement with other assets. Journal of Real Estate Finance and Economics, 5(4), 401-418. https://doi.org/10.1007/BF00174808

Lou, D., Polk, C., \& Skouras, S. (2015). A tug of war: Overnight versus intraday expected returns. SSRN Work. Pap. Retrieved from http://fbe.usc.edu/seminars/papers/F_1-30-15_LOU.pdf 
Lucca, D., \& Moench, E. (2015). The pre-FOMC announcement drift. Journal of Fiannce, 70, 329-371. https://doi.org/10.1111/jofi.12196

Mei, J., \& Liu, C. (1994). The predictability of real estate returns and market timing. Journal of Real Estate Finance and Economics, 8(2), 115-135. https://doi.org/10.1007/BF01097033

Ong, S. E., Ooi, J. T. L., \& Kawaguichi, Y. (2011). Seasoned Equity Issuance by Japan and Singapore REITs. The Journal of Real Estate Finance and Economics, 43, 205-220. https://doi.org/10.1007/s11146-010-9285-9

Pastor, L., \& Stambaugh, R. F. (2003). Liquidity risk and expected stock returns. Journal of Political Economics, 111, 642-685. https://doi.org/10.1086/374184

Prombutra, W., Phengpisa, C., \& Zhang, Y. (2012). What explains the investment growth anomaly? Journal of Banking \& Finance, 36, 2532-2542. https://doi.org/10.1016/j.jbankfin.2012.05.010

Tang, C. K., \& Mori, M. (2017). Sponsor Ownership in Asian REITs. The Journal of Real Estate Finance and Economics, 55, 265-287. https://doi.org/10.1007/s11146-016-9577-9

Wang, H., \& Liu, X. (2014). The Impact of Investor Heterogeneity in Beliefs on Share Repurchase. International Journal of Econometrics and Financial Management, 2(3), 102-113. https://doi.org/10.12691/ijefm-2-3-3

Wang, J. (1994). A Model of Competitive Stock Trading Volume. Journal of Political Economy, 102, 127-168. https://doi.org/10.1086/261924

Watanabe, A., Xu, Y., Yao, T. \& Yu, T. (2013). The asset growth effect: Insights from international equity markets. Journal of Financial Economics, 108, 529-563. https://doi.org/10.1016/j.jfineco.2012.12.002

\section{Copyrights}

Copyright for this article is retained by the author(s), with first publication rights granted to the journal.

This is an open-access article distributed under the terms and conditions of the Creative Commons Attribution license (http://creativecommons.org/licenses/by/4.0/). 